Management and
Business Research
Quarterly
MBRQ_

\title{
Evaluation of the Barriers to Achieve a Powerful Brand Using AHP Technique
}

\author{
Hamideh Seifi Shojai*, Hossein Boudaghi Khajeh Noubar \\ Young Researchers and Elite Club, Tabriz Branch, Islamic Azad University, Tabriz, Iran \\ Associate Prof., Faculty of Management, Islamic Azad University, Tabriz, Iran
}

Received 27 November 2018 Accepted 25 December 2018

\begin{abstract}
One of the most important factor in business is known as a brand. Despite all its potential, Iranian carpet is not branded well. The present study has been conducted in order to identify and prioritize the main factor of failure in achieving a powerful brand in commercial carpet companies. For this reason, the analytic hierarchy process (AHP) method used for data analysis. The nine main criteria and forty sub-criteria were identified based on the literature review. The highest importance weight obtained by the lack of brand management with 0.196 . Customization and market orientation with (0.171) placed in the second rank. Production and quality with (0.129) placed in the third priority. Marketing capabilities familiarity with $(0.111)$ and communications with (0.111) obtained the same rank. The rest of criteria were placed as following priority; appropriate business environment with $(0.096)$, information about the product with $(0.080)$, profitability with (0.069), and standard with $(0.038)$ respectively. The results of this study could be used by managers of the commercial companies to improve and retrieve their organizational processes to achieve powerful brand. Even though the research shed a light on the topic, however, future work can focus on developing a conceptual framework and can be investigated using other decision-making methods.

Keywords: Brand, Barriers of Carpet Brand, Powerful Brand, AHP, Tabriz Carpet
\end{abstract}

\section{Introduction}

Studies over the past twenty years has shown that the role of brands in value, risk reduction and increase of business life is undeniable. As a result, one of the most valuable assets of a complex is its brand or brands. Further, one of the senior manager's tasks in any organization is to create powerful brands. In fact, brand is the soul of a product. If you add a soul specific to your product, and equip it with emotion, story, difference and reputation, then you can create a brand (Kaypak, 
2013). In the era of identity, the goal of a brand is to play a role to identity brand's position in the market as well as the separating factor of commercial and personal products in terms of both appearance and speech among the majority of people. At the moment, customers cannot spend a lot of time to compare options; even if they have the time, they are not able to confidently identify the right product or service. Accordingly, it is the brand that transmits certainty (Kapferer, 2008).

The development of brand extension is used to encounter the market changes. For successful development of a brand, its coordination with the nature as well as its suitability with the brand's perspective is necessary. If the brand trends toward the development of products' group or customers' be in a one direction other than its nature, then they are both exposed to risk (Heding,2008). Because of the enormous changes in today's competitive market environment, building a successful brand is known as a one of the most important issues and the best business practices has been considered it (Aaker, 1997). Competition in market has given its place to the competition in mind through the brands (Toksar1 et al., 2014). So, many companies build their brand around their business. Therefore, first it must be asked for questions about business and then be held accountable for the same questions (Di Somma, 2014). Brand's strength leads to the strength of the competitive position against the increasing power of retailers (Park, Srinivasan, 1994). One of the models to create a stronger brand is the consumer-based brand equity model. The logic of this model is how consumers over time feel and see the brand, and what they learn. Brand's power is the extent that it remains in the minds of consumers (Keller,2001). A strong brand can increase customer's confidence when purchasing goods and services and helps them to better understand the intangible factors, in other words, we can say that a strong brand is an important asset for companies (Chen, \& Chang, 2008); the more the social power of a brand is, the higher the consumer-based brand equity will be (Crosno, Freling, \& Skinner 2009).

Iranian carpet industry suffers from a lack of brand strategy formulation and strategy definition of the business requirements in national scope. The creation of national brands is one of the influential factors to establish a position in global markets, and the development of a strategy to promote the country's national brand should be immediately undertaken. If we can steer investment towards good brands and reputation, carpet manufacturing that has been closed or are operating below capacity, can hope to continue their business. The truth is that there is no credible commercial of Iranian brand in international markets. The approach of industrialists and manufacturers just focus on the production and they do not have a special program for the branding and the role in creating a worthy place for itself in global markets. This research could be a debut for managers and marketing scholars for a proper outlook to a powerful brand, i.e. to view the brand from the aspect of the public's mentality, and for branding activities (from the standpoint of the public). Therefore, the aim of this study is to identify and prioritize the barriers to achieve powerful brand in Iranian carpet companies located in Tabriz city. According to the literature, no research has been conducted in this area and that is why the owners of this industry can donate a lot of contribution. The structure of the study charted as follows: section two describes the literature review. In section three research methodology is given. Section four discusses the case study. The results and managerial implications stated in section five and finally, conclusion and future guideline outlined in section six. 


\section{Literature review}

Brand managers as an intangible assets are valuable resource, since it can yield efficiency and effectiveness and helps them build strong brands. They represent a rare source for the company, since they depend on their management talent to produce stable competitive advantage. In addition, brand managers interact with a large number of parties, both inside and outside the company. These relationships form a socially complex resource, which cannot be completely imitated by others.

Eventually, while a firm can displace brand managers, the brand management intangible capital embedded in the brand managers cannot be easily superseded, especially tacit brand management knowledge and capabilities that one has already extended for brand management. In general, it can be truly said that the intangible capital of a brand manager satisfies the four criteria as a form of resources and provides a foundation to yield excellent brand performance. While both tangible and intangible resources are significant, researchers established that the competitive positioning of a firm may be found on heterogeneous resources (Hitt, Bierman, Shimizu, \& Kochhar, 2001; Hughes \& Morgan, 2007; Hunt, 2000), which is available in intangible capital (Nath \& Mahajan, 2011). According to Cui, Hu, Griffith (2014), marketing researchers have neither discovered marketing specific intangible capital, nor the type of specific intangible capital that is important to brand managers.

The authors engage in an iterative process to identify and create measures to effectively assess the factors necessary for understanding brand manager intangible capital and brand management capabilities. By developing measures for this purpose, this study not only provides specificity to allow for greater academic research, but also provides tools for assessing the intangible capital and brand management capabilities of brand managers. Therefore contribution is not only to academic discipline, but also to marketing practice and marketing education. Besides, building upon the literature within marketing focused on understanding marketing professionals as key firm resources (e.g.,Dickson, 1992; Griffith \& Lusch, 2007; Nath \&Mahajan, 2011; Verhoefet al., 2011). This study provides a theoretical and empirical foundation for future research on brand managers, tools for assessing current brand manager capital and capabilities, and guidance in relation to intangible capital and capabilities needed by brand managers.

Adina et al, (2015), stated that country-of-origin brand can influence the perceived brand positioning by reducing perceived risks, acting as a guarantee and enhancer for the positioning strategy. Also it can influence consumers' buying decision process and offer a significant competitive advantage. At the other hand, country-of-origin associations can negatively affect the brand positioning strategy. Nawel \& Ruiliang (2015) demonstrated that, following the increasing popularity of private brands, national brands' manufacturers are using many strategies either to counter the threat of these brands or to collaborate with retailers. They investigated the benefit of using national brands advertising (the aggressive strategy) that hurts the private labels of demand over using revenue sharing of national brand (the partnership strategy) that fosters collaboration between the retailer and the manufacturer national brands. Kunkel et al, (2014), explored the branding of sport leagues that represents an emergent area of scholarship. The research was an opportunity to explore the strategies sport leagues can implement to develop their brand and consequently better satisfy their consumers. They also explored sport brand development strategies 
within the context of a professional sport league. Professional sport leagues represent highly visible and valuable brands that require strategic development. These brands reflect consumers' overall evaluation of the league based on the attributes and benefits that the league provides. However, these strategies may not be financially feasible or may collide with the league's overall brand approach. Therefore, leagues need to conduct market research to investigate the feasibility of recommended brand development strategies and link them to their overall brand identity. Mindrut et al (2015) explained that the components of a brand identity are going to be in order to have a hierarchy of importance and extent of the study impact. Brand Nescafé are case studies in the field. The primary research objective of creating a map to extent the impact on the perception of the consumer about product brand identity. According to Christou (2015) stated that trust in a social media brand has high influence in developing of brand loyalty that conducted in Greece. The survey results demonstrate that social media brand characteristics appear more important in their impact on a customer's trust in a brand. It was also established that trust in a travel social media brand is positively influencing brand loyalty. Michaelidou et al (2015) specified that nonprofit brand image plays an important role in shaping consumers' charitable donations and therefore nonprofit organizations must be aware of how consumers perceive them. This research examined nonprofit brand image and reported findings from three empirical studies, which aimed to offer a better conceptualization and measurement of the idea. Firms within territorial brands must carefully manage the quality of their inputs and outputs, since cohesion is a collective and individual key success factor. In consequence, territorial brands should maintain open communication with competitors and, if not already in place, at the very least create collective trademarks in order to increase their value (Charters\&Spielmannb, 2014). Seimiene \& Kamarauskaiteb (2014) showed that brand personality destroyed mainly by the bottle design and labels, colors, design and advertising. However, factors such as brand positioning in the market. Also typical user should understand that in the consumer's perception, the brand personality is important. Riebe et al, (2014) discussed that for both growth and decline, business unusual role is much stronger than unusual escape. The findings showed that business has been rated in the past, and suggested that management prospects are the reduction of escape. Simulations illustrated that the business is far more unusual to account for the improvement in profit from escaping unusual. Cox et al, (2014) proposed that internal brand management theory provided a framework to explore strategies that might increase operator buy into the destination brand, thus creating a more consistent brand experience for visitors. Semi structured interviews with members of a destination brand network indicated that highly centralized networks hinder operator buy into the destination brand. Informal communication via more personalized sub-networks rather than directive leadership appear to facilitate knowledge sharing and creates up port mechanisms that promote brand citizenship behaviors. This study advanced destination brand management theory and provided practical insights into destination brand management practices. Entrepreneurial mentality to develop innovative brand: a case study in education Jewelry conducted by Wongpreedee et al, (2015). This work reported the development of entrepreneurial mindsets in this environment and the diffusion of marketing and technological concepts in the industry. A dummy company was established, and it selected creative students from universities to role-play brand manufacturers selling products in 
international trading fairs. These activities began in 2009 and the careers of the key persons involved had been followed. The results showed that they are eager and persistent to do the business and develop their own brand right after graduation and some characteristics such as engagement, social responsibilities, participative behavior and honesty in business were displayed. The research analyzing destination branding and image from online sources: a web content mining approach directed by Költringer and Dickinger (2015). This study presented an automated web content mining approach. Using web content extraction method for extracting information from digital image is made up of three factors. Wei Ho (2015) studied, identify with community or company? an investigation on the consumer behavior in Facebook brand community. The aim of this study was to simultaneously identify the community and the company and to evaluate the consequences of behavior from the perspective of Facebook members of society. The results of this study showed that the interaction in Facebook community can be both identity and citizenship behavior consumer C-C increase.

Table 1: Summary of the previous researches

\begin{tabular}{|c|c|c|c|}
\hline Authors & Objects of the research & Measure/Variable & Research Method \\
\hline $\begin{array}{l}\text { Mindrut, } \\
\text { Manolica, } \\
\text { Roman, (2013) }\end{array}$ & $\begin{array}{l}\text { Create a map of the brand dimensions } \\
\text { and impact of identity on consumer } \\
\text { perception }\end{array}$ & $\begin{array}{l}\text { Logo- stationery- messages and actions- } \\
\text { products and packaging- signage- apparel } \\
\text { design- marketing collaterals }\end{array}$ & Correlation \\
\hline $\begin{array}{l}\text { Uslu, Durmus, } \\
\text { Kolivarc, (2013) }\end{array}$ & $\begin{array}{l}\text { Analyzing the brand equity of Turkish } \\
\text { airlines }\end{array}$ & $\begin{array}{l}\text { Brand awareness-Associations-Brand } \\
\text { loyalty-Perceived quality }\end{array}$ & $\begin{array}{l}\text { The conceptual framework } \\
\text { based on customer based brand } \\
\text { equity }\end{array}$ \\
\hline $\begin{array}{l}\text { Chiu,Tzeng, Li, } \\
\text { (2013) }\end{array}$ & $\begin{array}{l}\text { A new hybrid MCDM model } \\
\text { combining DANP with VIKOR to } \\
\text { improve e-store business }\end{array}$ & $\begin{array}{l}\text { Need recognition- Information search- } \\
\text { Evaluation of alternatives-Choice/Purchase- } \\
\text { Post-purchase behaviour }\end{array}$ & $\begin{array}{l}\text { DEMATEL /DANP/ VIKOR } \\
\text { methods }\end{array}$ \\
\hline $\begin{array}{l}\text { Charters, } \\
\text { Spielmannb, } \\
(2014)\end{array}$ & $\begin{array}{l}\text { Characteristics of strong territorial } \\
\text { brands: The case of champagne }\end{array}$ & $\begin{array}{l}\text { Territorial Brand (environment)- Destination } \\
\text { Brand (tourism)- Regional Brand }\end{array}$ & \\
\hline $\begin{array}{l}\text { Seimiene, } \\
\text { Kamarauskaiteb, } \\
(2014)\end{array}$ & (place association) & Based on qualitative research & \\
\hline $\begin{array}{l}\text { Riebe, Wright, } \\
\text { Stern, Sharpa, } \\
\text { (2014) }\end{array}$ & $\begin{array}{l}\text { How different brand elements, attributes } \\
\text { or factors shape in consumers' minds the } \\
\text { perception of brand personality }\end{array}$ & $\begin{array}{l}\text { Packaging- Logo design- Brand name- } \\
\text { Perceived price- Advertising- Producer- } \\
\text { Typical perceived user }\end{array}$ & The qualitative study \\
\hline $\begin{array}{l}\text { Cox, Gyrd- } \\
\text { Jones, } \\
\text { Gardiner, } \\
(2014)\end{array}$ & $\begin{array}{l}\text { Internal brand management theory } \\
\text { provides a framework to explore } \\
\text { strategies that may increase operator } \\
\text { buy-into the destination brand. }\end{array}$ & $\begin{array}{l}\text { Network structure- Communication } \\
\text { style- Leadership style- Stakeholder } \\
\text { satisfaction- Buy in- Brand } \\
\text { communication }\end{array}$ & Conceptual model \\
\hline $\begin{array}{l}\text { Michel, } \\
\text { Donthub, } \\
(2014)\end{array}$ & $\begin{array}{l}\text { Introduces the concept of brand } \\
\text { association centrality and } \\
\text { distinguishes central brand } \\
\text { associations (CBAs) and peripheral } \\
\text { brand associations }\end{array}$ & $\begin{array}{l}\text { CBAs: (Functional-Inexpensive- } \\
\text { Disposable) PBAs: (Practical- Simple- } \\
\text { Plastic- }\end{array}$ & Conceptual model \\
\hline $\begin{array}{l}\text { Kunkel,Doyle, } \\
\text { Funk, (2014) }\end{array}$ & $\begin{array}{l}\text { Exploring sport brand development } \\
\text { strategies to strengthen consumer } \\
\text { involvement with the product - The } \\
\text { case of the Australian A-League }\end{array}$ & $\begin{array}{l}\text { Involvement- Satisfaction with } \\
\text { management- Consumption }\end{array}$ & $\begin{array}{l}\text { Descriptive Statistics and } \\
\text { using IBM SPSS Statistics } \\
\text { version 19.0. }\end{array}$ \\
\hline $\begin{array}{l}\text { Christou, } \\
(2014)\end{array}$ & $\begin{array}{l}\text { Branding Social Media in the } \\
\text { Travel Industry }\end{array}$ & $\begin{array}{l}\text { Merits in speed- Economy- Control of } \\
\text { respondent type }\end{array}$ & Conceptual model \\
\hline
\end{tabular}




\begin{tabular}{|c|c|c|c|}
\hline $\begin{array}{l}\text { Aloini, ulmin, } \\
\text { Mininno, (2014) }\end{array}$ & $\begin{array}{l}\text { A peer IF-TOPSIS based decision } \\
\text { support system for packaging } \\
\text { machine selection }\end{array}$ & $\begin{array}{l}\text { Speed - Flexibility-Safety- Technological } \\
\text { parameters-User friendly-Accessories- } \\
\text { Upgrading- Guarantee and assistance-Price- } \\
\text { Consumption-Dimension }\end{array}$ & TOPSIS method \\
\hline $\begin{array}{l}\text { Amrouche,Yan, } \\
(2015)\end{array}$ & Aggressive or partnership strategy & Private labels (PLs)-national brands (NBs) & Survey \\
\hline $\begin{array}{l}\text { Költringer and } \\
\text { Dickinger, } \\
\text { (2015) }\end{array}$ & $\begin{array}{l}\text { How to extract destination brand } \\
\text { identity and image through web content } \\
\text { mining. }\end{array}$ & $\begin{array}{l}\text { Number of documents -Keywords in total - } \\
\text { Unique keywords -Categories represented }\end{array}$ & $\begin{array}{l}\text { Data mining and natural } \\
\text { language processing domain and } \\
\text { includes keyword analysis and } \\
\text { automatic sentiment detection }\end{array}$ \\
\hline $\begin{array}{l}\text { Ching-Wei Ho, } \\
(2015)\end{array}$ & $\begin{array}{l}\text { To investigate the behavioral } \\
\text { implications from the Facebook } \\
\text { community members' perspective. }\end{array}$ & $\begin{array}{l}\text {-Company's community on Facebook (CF) } \\
\text {-Consumer-community identification (CmI) } \\
\text {-Consumer-company identification (CpI) } \\
\text {-In-role behavior (In)-Ex-role behavior (Ex) }\end{array}$ & Partial least squares (PLS) \\
\hline $\begin{array}{l}\text { Michaelidou, } \\
\text { Micevs ki, } \\
\text { Cadogan, (2015) }\end{array}$ & $\begin{array}{l}\text { To offer a better conceptualization and } \\
\text { measurement of the concept }\end{array}$ & Usefulness-Efficiency-Affect-Dynamism & $\begin{array}{l}\text { exploratory factor analysis } \\
\text { (EFA) and confirmatory factor } \\
\text { analysis (CFA) analysis }\end{array}$ \\
\hline $\begin{array}{l}\text { Pedeliento, } \\
\text { Andreini, } \\
\text { Bergamaschi, } \\
\text { Salo, (2015) }\end{array}$ & $\begin{array}{l}\text { Brand and product attachment in an } \\
\text { industrial context and The effects on } \\
\text { brand loyalty. }\end{array}$ & $\begin{array}{l}\text { Brand loyalty-Brand attachment-Product } \\
\text { attachment- Product irreplaceability- Brand- } \\
\text { self congruity- Brand reliability- Product-self } \\
\text { congruity- Product reliability }\end{array}$ & Conceptual model \\
\hline $\begin{array}{l}\text { Zhang, Jiang, } \\
\text { Shabbir, } \\
\text { Du, (2015) }\end{array}$ & $\begin{array}{l}\text { Provide managerial implications for } \\
\text { building B2B brand equity by } \\
\text { leveraging firm's capabilities and co- } \\
\text { creating value with customers. }\end{array}$ & $\begin{array}{l}\text { Innovation capability- Marketing capability- } \\
\text { Networking capability-Value co-creation- } \\
\text { Customer value- Brand equity }\end{array}$ & Conceptual model \\
\hline $\begin{array}{l}\text { Davvetas, } \\
\text { Sichtmann, } \\
\text { Diamantopoulos } \\
\left(\begin{array}{ll}2015)\end{array}\right.\end{array}$ & $\begin{array}{l}\text { Determine the impact of perceived } \\
\text { brand globalization on consumers' } \\
\text { willingness to pay. }\end{array}$ & $\begin{array}{l}\text { Consumer ethnocentrism- Global identity- } \\
\text { Local identity- Cosmopolitanism }\end{array}$ & $\begin{array}{l}\text { Model in four complementary } \\
\text { studies covering distinct } \\
\text { product categories, WTP } \\
\text { measurement approaches and } \\
\text { PBG manipulations }\end{array}$ \\
\hline $\begin{array}{l}\text { Adina, Gabriela, } \\
\text { Denisaa, (2015) }\end{array}$ & $\begin{array}{l}\text { This article reviews the main country- } \\
\text { of- origin moderating factors and } \\
\text { analyzes their influence on consumers' } \\
\text { brand perceptions at a cognitive, } \\
\text { affective and normative level. }\end{array}$ & $\begin{array}{l}\text { Cognitive aspects- Affective aspects- } \\
\text { Normative aspects }\end{array}$ & $\begin{array}{l}\text { The findings of the previous } \\
\text { analysis (Analysis Method) }\end{array}$ \\
\hline $\begin{array}{l}\text { Lien, Wen, } \\
\text { Huang, Wu, } \\
\text { (2015) }\end{array}$ & $\begin{array}{l}\text { Examines the direct and mediating effects } \\
\text { of brand image, perceived price, trust, } \\
\text { perceived value on consumers' booking } \\
\text { intentions and compares the gender } \\
\text { differences in online hotel booking }\end{array}$ & $\begin{array}{l}\text { Brand Image- Price- Trust- Value- Purchase } \\
\text { Intentions }\end{array}$ & Descriptive Statistics \\
\hline $\begin{array}{l}\text { Majerovaa,, } \\
\text { Kliestikb, (2015) }\end{array}$ & $\begin{array}{l}\text { To detect the most convenient brand } \\
\text { valuation method in specific Slovak } \\
\text { conditions }\end{array}$ & $\begin{array}{l}\text { market approach, cost approach, income } \\
\text { approach. }\end{array}$ & $\begin{array}{l}\text { Modified soft selection } \\
\text { analysis }\end{array}$ \\
\hline $\begin{array}{l}\text { Dong, Cooper, } \\
\text { (2016) }\end{array}$ & $\begin{array}{l}\text { A peer-to-peer dynamic adaptive } \\
\text { consensus reaching model for the group } \\
\text { AHP decision making }\end{array}$ & $\begin{array}{l}\text { Wisdom, Experience, Previous performance, } \\
\text { persuasive abilities, Effort on problem }\end{array}$ & $\begin{array}{l}\text { The Analytic Hierarchy } \\
\text { Process(AHP) }\end{array}$ \\
\hline $\begin{array}{l}\text { Abdollahzadeh et } \\
\text { al, (2016) }\end{array}$ & $\begin{array}{l}\text { Selecting strategies for rice stem borer } \\
\text { management using the AHP }\end{array}$ & $\begin{array}{l}\text { Ease of use-Relative advantages-Technical } \\
\text { support-Compatibility-Trialability- } \\
\text { Observability-Farmer's self-efficacy- Farm } \\
\text { characteristics-Control effectiveness-Social } \\
\text { usefulness }\end{array}$ & AHP \\
\hline $\begin{array}{l}\text { Gao, Feng, } \\
(2016)\end{array}$ & $\begin{array}{l}\text { Branding with social media: User } \\
\text { gratifications, usage patterns, and brand } \\
\text { message content strategies }\end{array}$ & $\begin{array}{l}\text { Design of questionnaire: Social connections, } \\
\text { activities, and brand following on Renren and } \\
\text { Weibo. }\end{array}$ & $\begin{array}{l}\text { By a self-report questionnaire, } \\
\text { EFA }\end{array}$ \\
\hline
\end{tabular}




\begin{tabular}{lll}
\hline $\begin{array}{l}\text { Casidy, Wymer, } \\
\text { O'Cass, (2018) }\end{array}$ & $\begin{array}{l}\text { Enhancing hotel brand performance } \\
\text { through fostering brand relationship } \\
\text { orientation in the minds of consumers }\end{array}$ & $\begin{array}{l}\text { Consumer-Brand Identification, Positive } \\
\text { Anticipated Emotions, Involvement, } \\
\text { Perceived Brand Relationship Orientation, } \\
\text { Revisit Intention, Share of Wallet, } \\
\text { Consideration Set Size. }\end{array}$ \\
\hline $\begin{array}{l}\text { Giovanisa, } \\
\text { Athanasopouloub } \\
(2018)\end{array}$ & $\begin{array}{l}\text { To develop and test a model to } \\
\text { investigate the effect of three brand } \\
\text { relationship dimensions, namely brand } \\
\text { trust }\end{array}$ & $\begin{array}{l}\text { Integrity Benevolence, Competence, } \\
\text { Satisfaction, Commitment, Repurchase } \\
\text { Intentions, Positive Recommendations, Price } \\
\text { Tolerance }\end{array}$ \\
\hline
\end{tabular}

\section{Research model}

Information needed to collect from interviews, the formation of expert groups and questionnaires were used to collect data through AHP. According to the rules of the AHP, an important part of the weight assigned to each variable of proposed model is paired wise comparisons. The study also comments vendors to pairwise comparisons using questionnaires. The questionnaire was designed on the basis of the information required for AHP. These questionnaires are weighted based on the chart provided by Saaty. The research is completed in two overall stages: in the first stage, the main factors and components of research were identified through reviewing the related literature and the conceptual model were specified according to Figure 1. In the second phase, the data related to conceptual model variables were collected and evaluated through AHP method. The results of questionnaires were analyzed by using AHP method in Excel software In all questionnaires, 40 sub-criteria which are possible to be effective in country's carpet companies were represented in 9 main criteria as material, human resource, technical, economical groups. The identified criteria were rated by industrialists, professors, experts and specialists in the form of a questionnaire. Finally, the importance rate of each sub- criteria applied by using AHP method.

\section{Overview of the study}

The Analytic Hierarchy Process (AHP) has been widely applied to group decisions because of the flexible structure and ability to make relative comparisons. Allocating the weight or importance to each individual with in a group is an important component in the decision process and plays a key role in obtaining the final solution in AHP. In the past three decades multiple methods have been proposed to determine the weights of individual (Saaty, 1994). This study uses AHP for determining strategies for the barriers to achieve powerful brand in Iranian carpet commercial companies. The collected data were analyzed by Expert Choice software. Accordingly, after collecting the questionnaire submitted to the relevant participating retailers, consistency rate calculated as 0.09 . Since it was lower than 0.1 is acceptable.

The methodology implemented in following steps: 


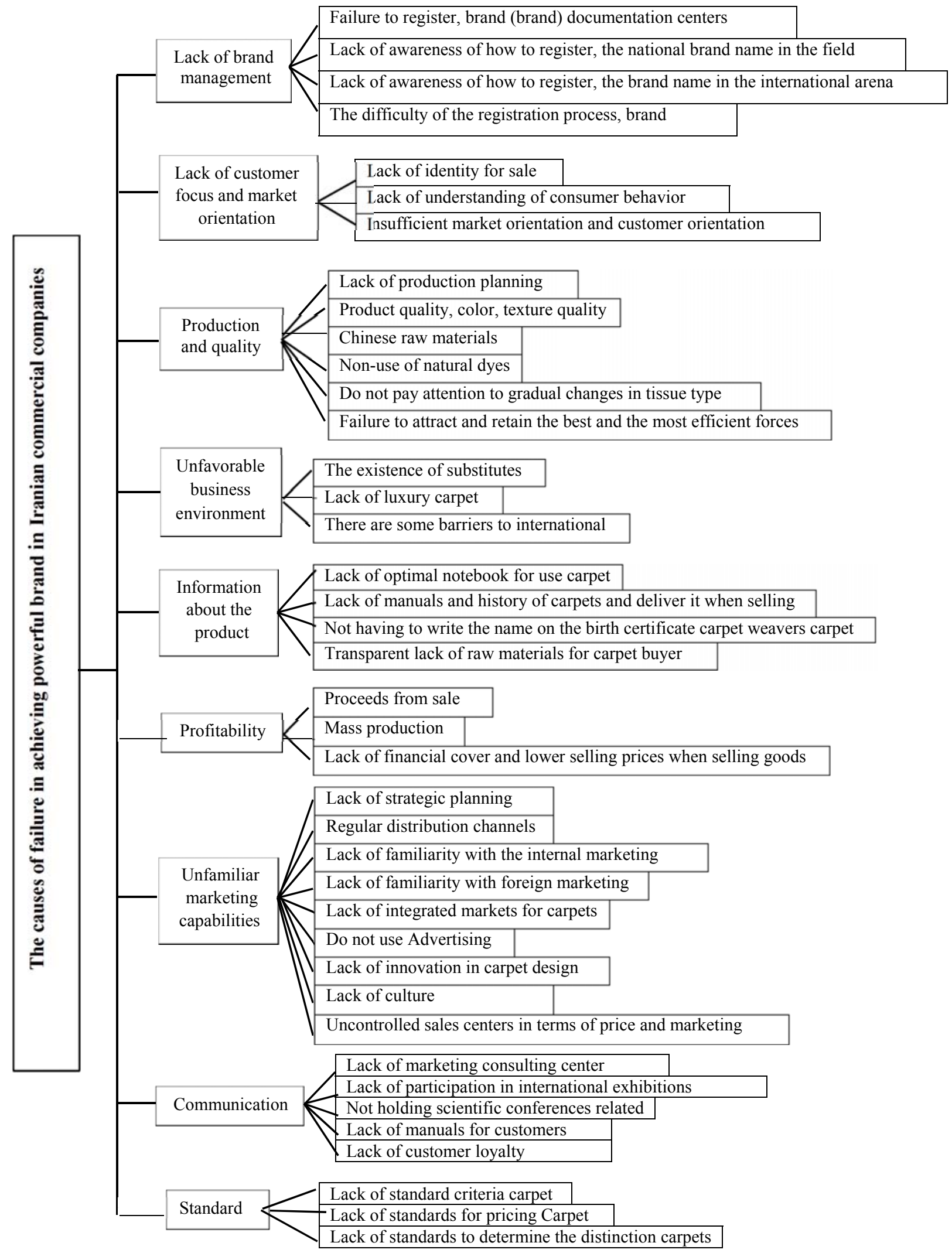

Figure 1.hierarchy of the problem. 
Step1: Define the problem and establish a hierarchical structure.

A hierarchical structure includes three levels: The ultimate goal in the first row, the second row to define multiple criteria (sub-criteria exist if the line is) and options for decision-making is the bottom line. The Figure 1 illustrates the hierarchy of the problem.

Step2: Pair-wise comparison and measurement of variables.

In AHP, multiple pair-wise comparison performs based on the scale proposed by Saaty which shown in Table 2. The pair wise comparison of variables were conducted by managers and assistance managers of company X. After pair-wise comparison finished, the matrix made which through it the relative weight of factors was calculated. The judgments are recorded in a matrix, which describes a set of equations that can be solved for the Eigen vector. This vector gives the normalized weights. It is confirmed that a scale of nine units is reasonable and reflects the degree to which humans can quantify relationships among factors.

Table 2. Numerical assignments for pairwise comparison

\begin{tabular}{ccl}
\hline $\begin{array}{l}\text { Numerical } \\
\text { scale }\end{array}$ & Verbal scale importance & Explanation \\
\hline 1.0 & Equal & Two factors contribute equally. \\
3.0 & Moderate & Experience and judgment favor one factor over another. \\
5.0 & Strong & A factor is strongly favored. \\
7.0 & Very strong & A factor is very strongly dominant. \\
9.0 & Extreme & A factor is favored by about an order of magnitude of difference. \\
$2.0,4.0,6.0,8.0$ & intermediate value between two & Used for compromise between two judgments. \\
& adjacent judgments & \\
\hline
\end{tabular}

Generally, a pair wise comparison matrix is shown as following which $a$ is the prefer factor of $i$ to factor $j$.

$\mathrm{A}=\left[\begin{array}{ccc}a_{11} & a_{12} & \ldots a_{1 n} \\ a_{21} & a_{22} & \ldots a_{2 n} \\ a_{n 1} & a_{n 2} & \ldots a_{n n}\end{array}\right] n \times n \quad \mathrm{~A}=\left[a_{i j}\right] \quad i, j=1,2, \ldots, n$

Step3: Calculating the rate of Inconsistency Index

All calculations based on AHP judgment matrix comparing the primary decision makers appear to be done and any errors and inconsistency in comparing the importance of the options and parameters, undermine the final result obtained from the calculation. In other words, the third step should ensure that there is a logical consistency between pair-wise comparisons because AHP output quality is strongly related to compatibility of pairwise comparison. So, at this stage rate of incompatibility should be calculated. The maximum eigenvalues of matrix of pairwise comparisons $(\lambda \max )$

$I R=\frac{I I}{I R I}$

Where IRI (random index) represents the average consistency index over numerous random entries of same order reciprocal matrices and is depended on the size of matrix than shown in Table 3. If IR 0.1 , the estimate is accepted; otherwise a new comparison matrix is solicited until IR 
0.1. is needed to be calculated. The inconsistency index is calculated from the following equation:

Table3: Distribution of RI (random index) by matrix size $(n * n)$.

\begin{tabular}{llllllllllllllll} 
Size of matrix (n) & 1 & 2 & 3 & 4 & 5 & 6 & 7 & 8 & 9 & 10 & 11 & 12 & 13 & 14 & 15 \\
\hline Random index & 0.00 & 0.00 & 0.58 & 0.90 & 1.12 & 1.24 & 1.32 & 1.41 & 1.45 & 1.49 & 1.51 & 1.52 & 1.56 & 1.57 & 1.59
\end{tabular}

\section{Stage 4: prioritizing}

By final calculated scores alternatives can be prioritized and choose the best one. At last, by the final calculated weight, the nine main criteria and its sub-criteria prioritized and the results are summarized in the tables 4 as follows:

\begin{tabular}{lllc} 
Table 4: Prioritizing of factors & & & \\
\hline CI & Wi & IR & Rank \\
\hline Lack of brand management & 0.196 & 0.05 & 1 \\
\hline Lack of customer-oriented and market-oriented & 0.171 & 0.00 & 2 \\
\hline Production and quality & 0.129 & 0.06 & 3 \\
\hline Being unfamiliar marketing capabilities & 0.111 & 0.08 & 4 \\
\hline Communications & 0.111 & 0.04 & 5 \\
\hline Inappropriate business Environment & 0.096 & 0.00 & 6 \\
\hline Information about the product & 0.080 & 0.04 & 7 \\
\hline Profit & 0.069 & 0.04 & 8 \\
\hline Standard & 0.038 & 0.05 & 9 \\
\hline
\end{tabular}

\section{Case Study}

The phenomenon of mass production pushing countries to mandatory export. Domestic markets of countries witness the arrival of a variety of exported goods that sometimes, owing to more advantages in comparison with homegrown products, engulf the market. Governments, due to financial constraints, had to remove the extensive support of domestic products, and they even resorted to foreign products to provide their needs with cheaper sources. It is obvious that in such a competitive and stressful atmosphere, those firms mired in their cocoon, having good hearts owing to their safety margin, are not prepared to deal with the pressure and will have a chance to survive. Experts predict that changes will occur in Iran's economy over the next few years whereby the subsequent import restrictions will be entirely eliminated, and government-paid subsidies especially in industry will be eliminated or reach the minimum. On the other hand, as in other countries in the global trading system, small manufacturers will have to resort to integration into each other in order to establish larger working groups.

The lack of proper understanding of the effective factors in the competitiveness of Iran's carpet industry has caused a significant increase in importing rate during the recent years. By considering the target markets, it is found that the rate of carpet exports has increased as the rival countries have opened their markets to Iranian products. However, lack of attention to standardization issues and quality of products cause their markets to have a negative reaction toward Iranian products. The mentioned factor along with negative competition of Iranian exporters with each other, lack of future vision, export of low quality products, and the presence of powerful rivals such as India, Pakistan and China decreased the volume of Iran's export to the mentioned markets. Finding the 
obstacles and difficulties faced by carpet industry as well as the reasons for its backwardness in comparison with other countries can represent more effective solutions to operate them in the country and develop the exporting process. Therefore, the creation of special industrial zones and the specialization of tasks can be an effective step to improve quality and develop Iran's carpet export. Lack of sustainable policy for the production, failure to provide appropriate financial facilities for manufacturers by the banks, worn equipment and machineries as well as lack of adequate human resources specialists are among the major problems in the country's furniture manufacturing industry. Failure in exporting carpet as well as losing regional markets in favor of countries such as Turkey and China is rooted in factors other than a lack of raw materials and manufacturing structures. It is necessary to pay more attention to the use of knowledgeable managers, practical training, strong support of exporters and domestic producers and the need for innovation in different fields. The carpet Industry is currently facing various challenges and unfortunately, there are no coherent and comprehensive programs to deal with them. In this regard, we always witness incomplete, contradictory and short-term solutions and in some cases even incorrect ones. Lack of cohesion, neutralization of other activities, and inaction statues are among the consequences of the absence of a roadmap agreed by the various active and influential sections in this industry, which impose exorbitant costs as a result of losing opportunities for the development of the country's wooden industry and even the previous conditions.

\section{Results}

The AHP was applied in Tabriz city located in East Azarbaijan in Iran. The main aim of this research was to identify and prioritize the barriers to achieving powerful brand in Iranian commercial companies. The following nine main criteria identified as; lack of brand management, lack of customer and market orientation, production and quality, inappropriate business environment, information about the product, profitability, unfamiliar to the marketing capabilities, communication standard. The highest degree of importance to the lack of brand with 0.196 and the lowest degree of importance to the standard with 0.038, is dedicated as it shown in Figure2.

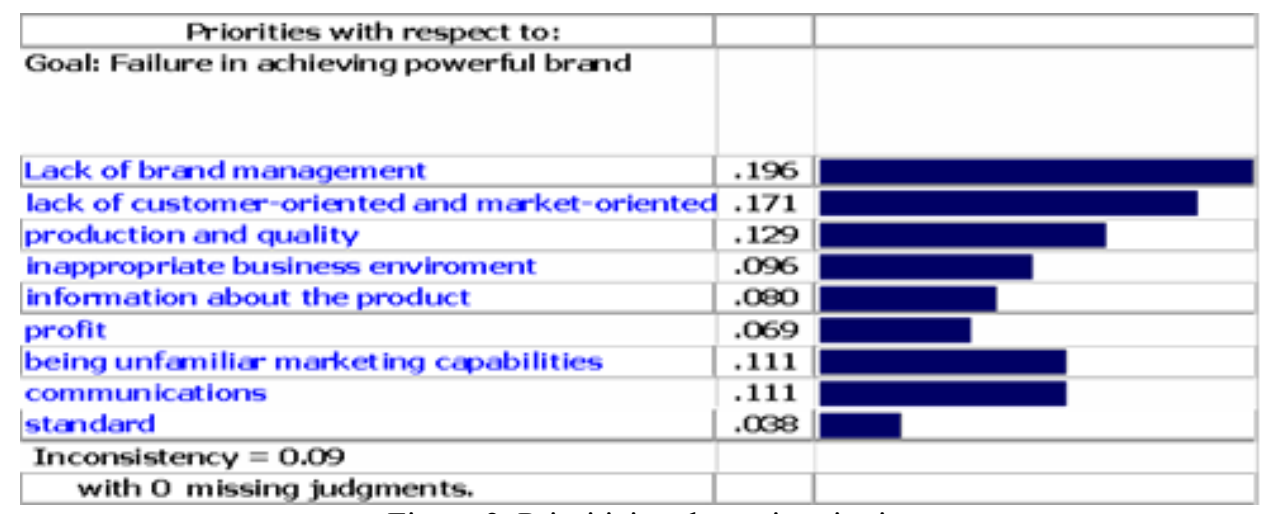

Figure 2. Prioritizing the main criteria

In the group of lack of brand management, the highest degree of importance to the lack of brand registration with 0.343 and the lowest degree of importance to the difficult registration process with 0.172 is dedicated as it illustrated in Figure 3. 


\begin{tabular}{|c|c|c|}
\hline Priorities with respect to: & & \\
\hline $\begin{array}{l}\text { Goal: Failure in achieving powerful brand } \\
>\text { Lack of brand management }\end{array}$ & & \\
\hline lack of brand registration & .343 & \\
\hline lack of awareness in the national register & .243 & \\
\hline lack of awareness in the intemational reg & .243 & \\
\hline difficult registration process & 172 & \\
\hline Inconsistency $=0.05$ & & \\
\hline
\end{tabular}

Figure 3. Prioritizing of sub-criteria in lack of brand management group

In the group, lack of customer focus and market orientation, all the criteria obtained the same rank with 0.33 as it depicted in Figure 4.

\begin{tabular}{l}
\hline \multicolumn{1}{|c|}{ Priorities with respect to: } \\
\hline $\begin{array}{l}\text { Goal: Failure in achieving powerful brand } \\
\text { > lack of customer-oriented and market-oriented }\end{array}$ \\
\begin{tabular}{|l|l|l|}
\hline lack of identity for carpet & \\
\hline failure to understand consumer behavior & .333 & \\
\hline lack of marketing orientation and customer orientation & .333 & \\
\hline Inconsistency = 0. & & \\
\hline with 0 missing judgments. & & \\
\hline
\end{tabular}
\end{tabular}

Figure 4. Prioritizing of sub-criteria in customer focus and market orientation group

In the group, lack of production and quality, the highest degree of importance given to the lack of production planning with 0.429 and the lowest degree of importance to the failure to attract and retain the best and the most efficient forces with 0.047 as it shown in Figure 5.

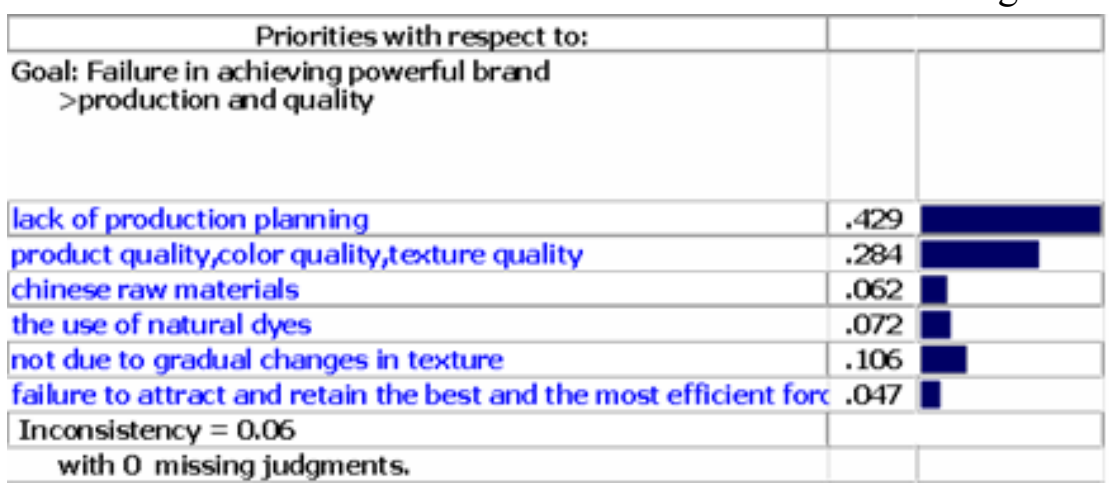

Figure 5. Prioritizing of sub-criteria in production and quality group.

In the group of unfavorable business environment, the highest degree of importance belonged to the existence of substitute with 0.732 and the lowest degree of importance to the lack of luxury carpet with 0.130 as it shown in Figure 6. 


\begin{tabular}{l}
\hline Priorities with respect to: \\
\begin{tabular}{|l|}
\hline Goal: Failure in achieving powerful branc \\
> inappropriate business enviroment
\end{tabular} \\
\begin{tabular}{|l|} 
the existence of substitutes \\
no luxaury carpet
\end{tabular} \\
\hline there are some barriers to intemational \\
\hline Inconsistency = 0.00352 \\
with 0 missing judgments.
\end{tabular}

Figure 6. Prioritizing of sub-criteria in unfavorable business environment group.

In the group of information about the product, the highest degree of importance given to the lack of manuals and history of carpets and deliver it when selling with 0.40 and the lowest degree of importance to the not having to write the name on the birth certificate carpet weavers with 0.144 as it shown in Figure 7.

\begin{tabular}{|c|c|c|}
\hline Priorities with respect to: & & \\
\hline $\begin{array}{l}\text { Goal: Failure in achieving powerful brand } \\
\text { >irformation about the product }\end{array}$ & & \\
\hline Lack of optimal notebook for use carpet & .278 & \\
\hline $\begin{array}{l}\text { Lack of } m \text { anuals and history of carpet and deliver it when sales } \\
\text { Not having to write the name on the birth certificate carpet weaver }\end{array}$ & $\begin{array}{r}.400 \\
.144\end{array}$ & \\
\hline $\begin{array}{l}\text { Not transparent raw materials for carpet buyer } \\
\text { Inconsistency }=0.04\end{array}$ & .178 & \\
\hline With 0 missing judgments. & & \\
\hline
\end{tabular}

In the group of profitability, the highest degree of importance obtained by proceeds from sale with 0.413 and the lowest degree of importance to the mass production with 0.260 as it shown in Figure 8.

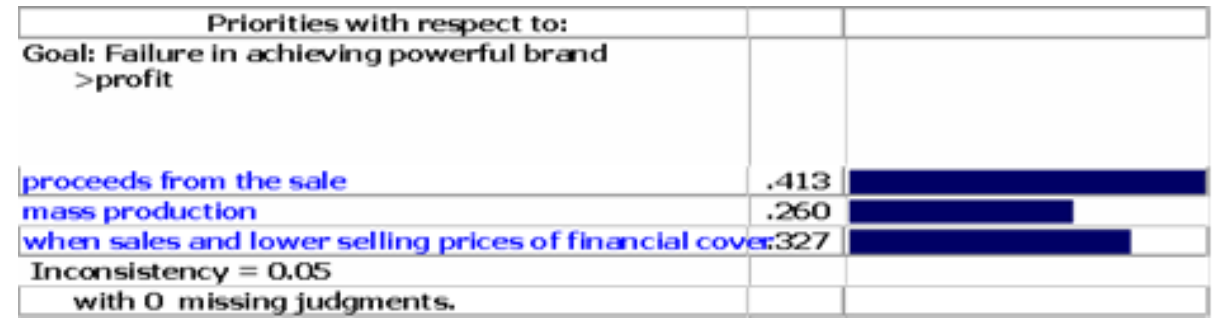

Figure 8. Prioritizing of sub-criteria in profitability group.

In the group of unfamiliar marketing capabilities, the highest degree of importance given to the lack of strategic planning with 0.282 and the lowest degree of importance to the lack of culture with 0.035 as it shown in Figure 9. 


\begin{tabular}{|c|c|c|}
\hline \multicolumn{2}{|l|}{ Priorities with respect to: } & \\
\hline \multicolumn{2}{|l|}{$\begin{array}{l}\text { Goal: Failure in achieving powerful brand } \\
\text { >being unfamiliar marketing capabilities }\end{array}$} & \\
\hline lack of strategic planning & .282 & \\
\hline regular distribution channels & .077 & \\
\hline lack of familiarity with local markets & .150 & \\
\hline lack of familiarity with foreign markets & .136 & \\
\hline lack of integrated markets for carpet & .069 & \\
\hline do not use the media & .070 & \\
\hline lack of innovation in the design of carpet & .129 & \\
\hline lack of culture & .035 & \\
\hline \multicolumn{3}{|c|}{ not control centers in terms of sales and marketing .053 } \\
\hline Inconsistency $=0.08$ & & \\
\hline with $\mathrm{O}$ missing judgments. & & \\
\hline
\end{tabular}

Figure 9. Prioritizing of sub-criteria in unfamiliar marketing capabilities group.

In the group of communication, the highest degree of importance assigned to the lack of participation in international exhibitions with 0.301 and the lowest degree of importance to the lack of customer loyalty with 0.082 as it shown in Figure 10.

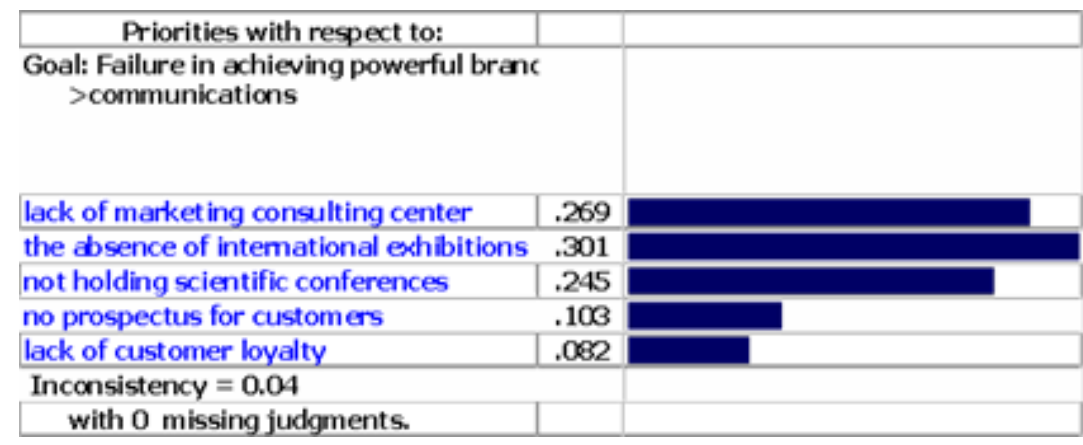

Figure 10. Prioritizing of sub-criteria in communications group

In the group of standard, the highest degree of importance given to the lack of standard for pricing carpet with 0.413 and the lowest degree of importance to the lack of to determine the distinction carpets with 0.260 as it shown in Figure 11.

\begin{tabular}{l}
\hline Priorities with respect to: \\
$\begin{array}{l}\text { Goal: Failure in achieving powerful brand } \\
\text { >standard }\end{array}$ \\
lack of standard criteria carpet \\
the lack of pricing standards for carpet \\
\begin{tabular}{|l|}
\hline lack of standards to determine the dist inction carpets. \\
Inconsistency $=0.05$
\end{tabular} \\
\hline with 0 missing judgments. \\
\hline
\end{tabular}

Figure 11. Prioritizing of sub-criteria in standard group.

\section{Discussion and Managerial implications}

According to the survey questions the most important barriers to achieve powerful brand in Iranian carpet companies identified and prioritized. So regarding to the meaning of any factors that indicate the status of companies (production or services), from the perspective of Tabriz carpet companies, the most important factor assigned to the brand management with (0.196). In 
the next place, customer and market orientation with (0.171), production and quality with $(0.129)$, unfamiliar to the marketing capabilities with $(0.111)$, communications with $(0.111)$, inappropriate business environment with (0.096), information about the product with (0.08), profitability with (0.069) and standard with (0.038) ranked respectively. Interpretation of results of sub-criteria in order of priority shown in Figure 12.

Synthesis with resped to: Goal: Failure in achieving powerful brand

Overall Inconsistency $=.07$

Lack of brand reqistration

Lack of identity for carpet

Failure to understand consumer behavior

Lack of marketinq orientation and customer orientation

Lack of awareness in the national reqister

Lack of awareness in the international reqister

Lack of production planning

Lack of strateqic planninq

The absence of international exhibitions

Difficult reqistration process

Lack of marketing consultinq center

The existence of substitutes

Not holdinq scientific conferences

Product quality, color quality, texture quality

No history book when sales

Proceeds from the sole

Lack of familiarity with local markets

No book is optimized for use carpet

When sales and lower sellinq prices of financial cover

Lack of familiarity with foreign

medketsinnovation in the design of carpet

Mass production

No prospectus for customers

The lack of pricing standards for carpet

Not transparent raw materials for carpet buyer

Not due to qradual chanqes in texture

Not having to write the name on the birth certificate carpet weaver

Requler distribution channels

Lack of customer loyalty

Lack of standard criteria carpet

Lack of integrated markets for carpet

Do not use the media

Lack of standards to determine the distinction carpets

The use of natural dyes

Not control centers in terms of sales and marketing

Chinese raw materials

There are some barriers to international

$$
\text { No luxury carpet }
$$

Failure to attract and retain the best and the most efficient force

Lack of culture

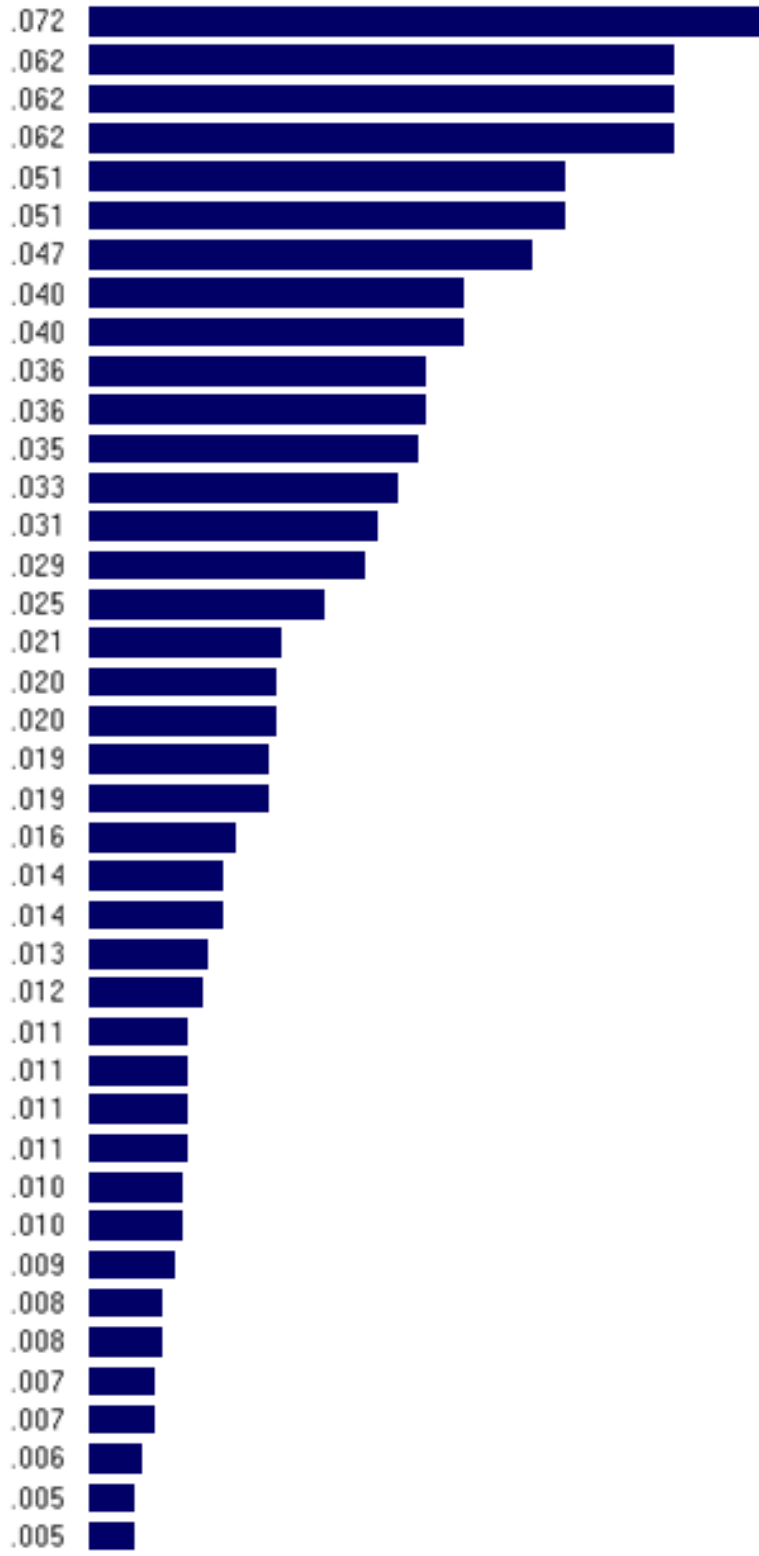

Figure 12. Overall priority of sub-criteria in descending order

\section{Conclusion}

According to the questionnaire of survey (that specifically includes: what are the failure causes 
of Iranian commercial firms in achieving powerful brands? What are the most powerful ones? And, how are they prioritized?), the results suggest that, out of the failure causes of Iranian commercial firms in achieving powerful brands, the first priority belongs to the lack of management. Also, lack of the factors, namely, customization and market orientation, production and quality, familiarity with marketing capabilities, communications, appropriate business environment, information about the product, profitability, and standardization constitute secondranked in sequence, respectively.

The review process of the research and its findings can be stated as follows:

In this study, pairwise comparisons of factors using AHP has been carried out in nine groups. So, regarding to the meaning of any of the factors that indicate the status of a company (production or services), from the perspective of Tabriz carpet companies, the most important factor is found to be the lack of brand management (0.196). The next ranks include the lack of the followings: customization and market orientation (0.171), production and quality (0.129), familiarity with the marketing capabilities (0.111), communications (0.111), appropriate business environment (0.096), information about the product (0.080), profitability (0.069) and standard (0.038).

In the group of brand management, the most important factor is the lack of registration in documents registration centers $(0.343)$ and the lowest level of importance belongs to the difficulty of the business registration process $(0.172)$.

In the group of customization and market orientation, identical importance levels are reported.

In production and quality group, the highest importance level belongs to the absence of production planning (0.429) and the lowest priority relates to the shortage in the enrollment and preservation of the best and the most efficient human sources (0.047).

In the group of unfamiliarity with marketing capabilities, the highest degree of importance is the lack of strategic planning $(0.282)$ and the lowest priority belongs to the lack of organizational culture (0.035).

In the group of communication, the most important factor is the absence of international exhibitions (0.301) and the lowest priority belongs to the lack of the creation of customer loyalty to the $(0.082)$.

In group of inappropriate business environment, the most important of all is the presence of substitutes and alternatives for the goods $(0.732)$ and the lowest priority relates to the nonluxuriousness of the carpet (0.130).

In the group of information about the goods, the highest level of importance is for the absence of booklets and history of the carpet and lack of its submission to the customer at the time of sale (0.400) and the lowest level belongs to the absence of weaver's name in the identification tag of carpet (0.144).

In the group of profitability, the highest degree of importance belongs to the income from the sales $(0.413)$ and the lowest priority relates to the mass production $(0.260)$.

In the standard group, the most important factor is the lack of standards for pricing (0.413) and the lowest priority belongs to the lack of standards to distinguish between the carpets (0.260).

The research findings can play an effective role in achieving powerful brand in the field of 
carpets that categorized as follows:

The brand management that can be performed best according to the following procedure. Registration of brands in documentation centers. Regarding the fact that Iran's commercial carpet system is extremely traditional and usually constituted of family-based firms, it is recommended that producers and businessmen be instructed with national and international brand registration methods. Awareness about the manner of national and international brand registration methods; that is, the unions and guilds be required to educate traders on how to register their brand and the benefits of brand registration be expressed.

For customer and market orientation, the ability to understand consumer's behavior should be considered. This means to take into account the consumer behavior as one of the primary strategies of the organization. Identity for carpet through naming and myth- making should be created.

For enhancing the quality and production and to have production planning and to deliver the product to the customer and having time-based goals for the final product that is the result of honesty in timely delivery of products.

Familiarity with marketing skills and capabilities is another key factor that is the first step of strategic planning. As a continuation, extensive use of public advertising, including TV, radio, Internet, street boards and so on, as well as the creation of integrated markets for carpets, along with the control of sales centers in terms of price and type of marketing, and improving public culture can be effective in enhancing the marketing skills.

Communication can be seen as an attendance or activity in international exhibitions, which makes it possible to directly deal with customers, competitors and suppliers, providing the background to attract new potential investors and exhibiting the new product in a way that is not possible via other marketing channels.

A suitable environment for business can be a main factor in achieving powerful brand. By providing an environment where similar goods can be offered instead of substitute goods and also by removing some international obstacles, and creating a reputation of uniqueness and luxuriousness of the carpets, it may be possible to create a background for achieving this goal.

Another major factor in this area can be the information about the product. Availability of booklet and the history of carpet, delivered when selling. A booklet on how to make optimal use of carpet and clarity and transparency of the materials used for carpet buyer. Also writing the name of the carpet weaver in the identification tag of carpet.

Profitability is another factor that can be considered for achieving a powerful brand. It may incorporate the identification of income from the sales, suitable financial power at the time of sale, and selling the goods with rational price.

For standardization some actions needed such as; having standards for carpet and carpet pricing. Also having standards for distinguishing between the carpets can be very helpful.

\section{References}

Aaker, J. L. (1997). Dimensions of brand personality. Journal of marketing research, 34(3), 347-356.

Adina, C., Gabriela, C., \& Roxana-Denisa, S. (2015). Country-of-origin effects on perceived brand positioning. Procedia Economics and Finance, 23, 422-427. 
Chen, C. F., \& Chang, Y. Y. (2008). Airline brand equity, brand preference, and purchase intentions-The moderating effects of switching costs. Journal of Air Transport Management, 14(1), 40-42.

Christou, E. (2015). Branding social media in the travel industry. Procedia-Social and Behavioral Sciences, 175, 607-614

Crosno, J. L., Freling, T. H., \& Skinner, S. J. (2009). Does brand social power mean market might? Exploring the influence of brand social power on brand evaluations. Psychology \& marketing, 26(2), 91-121

Cui, A. P., Hu, M. Y., \& Griffith, D. A. (2014). What makes a brand manager effective?. Journal of Business Research, 67(2), 144-150.

Di Somma, Mark .Think Brand First, Business Second, Branding Strategy Insider. [Online] Available: http://www.brandingstrategyinsider.com/brand-development.

Heding, T., Knudtzen, C. F., \& Bjerre, M. (2015). Brand management: Research, theory and practice. Routledge.

Kapferer, J. N. (2008). The new strategic brand management: Creating and sustaining brand equity long term. Kogan Page Publishers.

Tataroğlu, N., Karataş, A., \& Erboy, N. (2015). An evaluation on the process of being a brand city of Muğla. Procedia-Social and Behavioral Sciences, 210, 114-125.

Keller, K. L. (2001). Building customer-based brand equity: A blueprint for creating strong brands (pp. 3-27). Cambridge, MA: Marketing Science Institute

Kunkel, T., Doyle, J. P., \& Funk, D. C. (2014). Exploring sport brand development strategies to strengthen consumer involvement with the product-The case of the Australian A-League. Sport Management Review, 17(4), 470-483

Park, C. S., \& Srinivasan, V. (1994). A survey-based method for measuring and understanding brand equity and its extendibility. Journal of marketing research, 31(2), 271-288.

Saaty, T. L. (2000). Fundamentals of decision making and priority theory with the analytic hierarchy process (Vol. 6). RWS publications.

Mindrut, S., Manolica, A., \& Roman, C. T. (2015). Building brands identity. Procedia Economics and Finance, 20, 393-403 